\title{
A MULTIPLE CRITERIA DECISION SUPPORT SYSTEM FOR ANALYZING THE CORRELATION BETWEEN THE THICKNESS OF A THERMO-INSULATION LAYER AND ITS PAYBACK PERIOD OF THE EXTERNAL WALL
}

\author{
Donatas AVIŽA $^{\mathrm{a}, \mathrm{b}}$, Zenonas TURSKIS ${ }^{\mathrm{b}}$, Artūras KAKLAUSKAS ${ }^{\mathrm{c}}$ \\ ${ }^{a}$ Department of Technologies, Panevezys Faculty of Technologies and Business, Kaunas University of \\ Technologies, Daukanto st. 12-138, LT-35212 Panevėžys, Lithuania \\ ${ }^{b}$ Department of Construction Technology and Management, Vilnius Gediminas Technical University, \\ Sauletekio al. 11, LT-10223 Vilnius, Lithuania \\ cDepartment of Construction Economics and Real Estate Management, Vilnius Gediminas Technical University, \\ Sauletekio al. 11, LT-10223 Vilnius, Lithuania
}

Received 02 Feb 2015; accepted 23 Mar 2015

\begin{abstract}
A case study provides the correlation analysis of the thickness of the thermo-insulation layer (expanded polystyrene - EPS70) of the typical details of the external wall and energy performance class in a modern newly constructed residential low-energy building (one and two-room apartment). The conducted analysis focused on what impact different geographical areas of building construction and different energy performance classes of the building may had on the thickness of the thermo-insulation layer. Lithuania was chosen as the object of this study. Calculations were carried out in seven towns, including Vilnius, Klaipeda, Kaunas, Siauliai, Panevezys, Utena and Dukstas. According to requirements for legal acts passed in the Republic of Lithuania and to Directive 2010/31/EU (2010), as a result, the necessary thickness of thermo-insulation layers (EPS70) and a payback period were calculated. A multiple criteria decision support system for analyzing the correlation between the thickness of the thermo-insulation layer and its payback period of the external wall (DSS-ACTILPW) consisting of a database, a database management system, a model-base, a model-base management system and a user interface was developed. Information on the performed analysis is important to building designers, energy consumption auditors and investment experts who make the final decisions on energy efficiency of buildings in the residential building sector.
\end{abstract}

Keywords: residential low-energy building, thermo-insulation, payback period, energy performance class, correlation analysis, energy efficiency of buildings, external wall, multiple criteria decision support system.

\section{Introduction}

Residential buildings consume almost $40 \%$ of primary energy in the United States or Europe, and nearly 30\% in China (Deng et al. 2014). This sector has a large potential for energy savings (Kaynakli et al. 2012).

Residential housing accounts for around $75 \%$ of Europe's building stock (Fig. 1).

Directive 2010/31/EU (2010) on the energy performance of buildings will have an impact on energy efficiency in the European residential building sector.

All recently constructed buildings will have to be nearly of zero-energy buildings from 1 January 2021 (Marszal et al. 2012). These requirements shall be transposed into the national legal system.

Single-apartment residential buildings with almost unconsumed energy (nearly of zero-energy) are those of very high-energy efficiency where energy consumption equals to almost zero or is very low. These buildings mostly consume the energy produced from renewable sources on site or nearby. A++ class buildings can be attributed to this category in Lithuania (Aviza, Turskis 2014).

$$
\text { Source BPIE survey }
$$

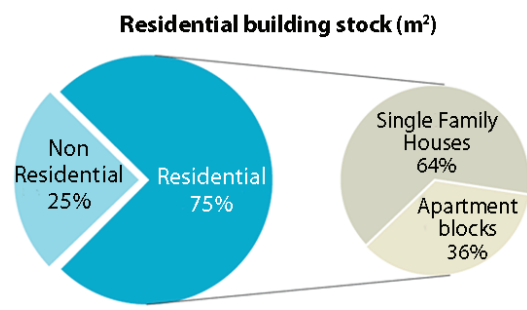

Fig. 1. Residential building stock, $\mathrm{m}^{2}$ (BPIE 2015)

Corresponding author: Donatas Aviža

E-mail:donatas.aviza@vgtu.lt 
Effectively designed and erected buildings with almost unconsumed energy (A++ class) appear as a big challenge not only for modern world countries but also for Europe. The experience and analysis of the encountered problem is limited. Therefore, scientific achievements in this direction are necessary and timely (Kurnitski et al. 2011).

Debates on similar problems occur on the international scale (Marszal et al. 2012).

The United States of America has signed the energysaving declaration The Energy Independence and Security Act of 2007 (2007), the main purpose of which is to move the United States toward greater energy independence and security, to increase the production of clean renewable fuels, to protect consumers, to increase the efficiency of products and buildings, to promote research on and to improve the energy performance of the Federal Government.

The problem of energy consumption and its management is also relevant to the Asian region. A sector of buildings in China is one of the largest energy consumers. Nearly 40 billion $\mathrm{m}^{2}$ of the usable area of buildings were built in China until 2006. The number of buildings is further growing. Chinese aim to increase energy efficiency up 20\% within the period of 5 years (Kong et al. 2012).

Energy saving is an important part of the Energy Policies of the European Union and the Republic of Lithuania (Ministry of Economy of Republic of Lithuania 2015). Promoting the use of sustainable energy resources is one of the most significant ways to increase the security of energy supply, to reduce the environmental impact of energy use and to promote the development of new industries, modern energy-efficient technology and the product market. Energy efficiency is the ability to get the most benefit from each unit of energy. Energy efficiency can be achieved by the rational use of energy and the application of energy saving technologies as well as by the employment of renewable energy resources. By saving energy, a higher quality of buildings is achieved. People living in these buildings have better living and hygienic conditions, which creates more jobs and increases work efficiency and productivity in the sectors of energy saving and innovative product development. This way, consumers and public funds can be saved and environmental pollution can be reduced. Thoughtful energy use and its saving can lead to win-win solutions. Such behaviour contributes to the economic growth and protection of the environment, enhances national security and reduces dependence on imported fuel suppliers. The efficient use of energy in the building is the result of a complex application of various measures.

To increase energy efficiency in the Lithuanian building sector is also a big challenge. The official database of building energy certification can be found in the Lithuanian Certification Center of Building Products (SPSC 2015). According to the requirements for legal acts passed in the Republic of Lithuania and considering

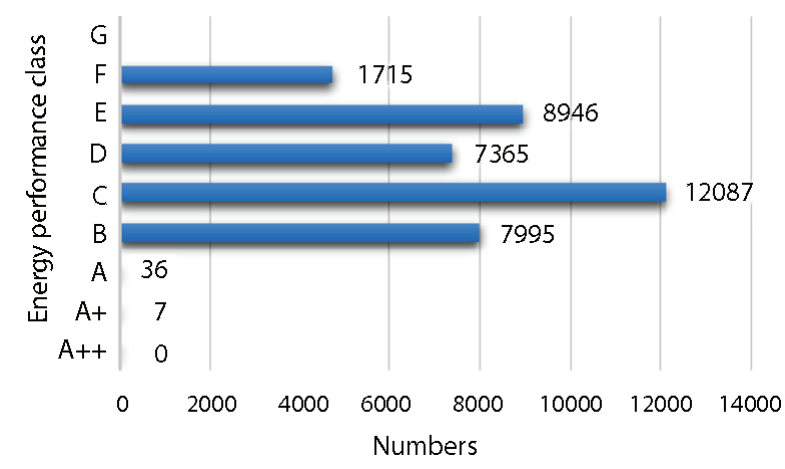

Fig. 2. Energy performance certificates of buildings in Lithuania (22-01-2015) (SPSC 2015)

European standards - the buildings of classes B, A, A+ and higher can be called low-energy buildings (BUILD UP skills - Lithuania 2013). Mainly, recently constructed buildings in Lithuania fall into the groups of energy performance classes C and B (12087 and 7995 certificates), 36 buildings can be attributed to class $\mathrm{A}, 7$ buildings belong to class $\mathrm{A}+$ and no buildings have reached class A++ so far (Fig. 2).

To pass from minimum requirements for classes $\mathrm{C}$ and $\mathrm{B}$ of the energy efficiency of newly constructed buildings to class $\mathrm{A}++$, it is important to assess climatic parameters and the influence of payback on the final decision (Aviza, Turskis 2014).

This task is of utmost importance in the residential building sector. Over $55 \%$ of the total building area in Lithuania consists of residential buildings and exceeds 100 million $\mathrm{m}^{2}$ according to data provided by the Lithuanian Department of Statistics (Statistics Lithuania 2014). In total, 400 thousand single-apartment residential buildings with their home gardens make up about a half of this area.

The study is aimed at developing correlation functions and determining links between the thickness of the thermal isolation layer of the wall (expanded polystyrene - EPS70) and its payback time according to the energy performance class of the building and the geographical area of building construction. Then, the authors of this paper present DSS-ACTILPW.

\section{Object description}

As for Lithuania, according to the currently valid normative requirements and provisions of STR 2.01.09:2012 Energy Performance of Buildings. Certification of Energy Performance (2012), buildings are classified and divided into 9 energy efficiency classes, including $\mathrm{A}++, \mathrm{A}+, \mathrm{A}, \mathrm{B}$, C, D, E, F and G (Fig. 3). The efficiency of energy consumption in the lately erected buildings (building parts) in Lithuania must not be lower than energy performance class B by 2016.

Traditional single-apartment residential buildings of new construction in Lithuania are built and designed according to the provisions of technical regulations on con- 


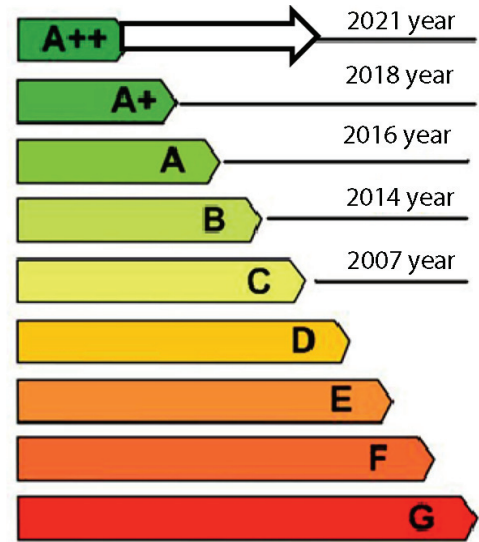

Fig. 3. Classification of the energy performance classes of buildings (periods of time): Class $\mathrm{G}$ indicates an energy-inefficient building; $\mathrm{A}++$ indicates a highly energy-efficient building

struction STR 2.01.09:2012 (2012), which means that often minimum requirements for energy efficiency classes $\mathrm{C}$ and $\mathrm{B}$ are reached.

To make buildings more energy efficient, minimum energy performance requirements have been raised since 2007 in order to achieve A++ class requirements for buildings with almost unconsumed energy (nearly of zero-energy) performance.

Normative requirements for the wall partitions of residential buildings of the one and two-room apartment have been investigated in the study (Table 1).

Table 1. Normative value of the thermal transmittance coefficient of walls in residential buildings $U_{N . w}, \mathrm{~W} /\left(\mathrm{m}^{2} \cdot \mathrm{K}\right)$

\begin{tabular}{c|c|c}
\hline No & $\begin{array}{c}\text { Energy } \\
\text { performance class }\end{array}$ & $U_{N . w,}, \mathrm{~W} /\left(\mathrm{m}^{2} \cdot \mathrm{K}\right)$ \\
\hline 1 & $\mathrm{C}$ and B & $0.20 \cdot \kappa$ \\
\hline 2 & $\mathrm{~A}$ & $0.12 \cdot \kappa$ \\
\hline 3 & $\mathrm{~A}+$ & $0.11 \cdot \kappa$ \\
\hline 4 & $\mathrm{~A}++$ & $0.10 \cdot \kappa$ \\
\hline
\end{tabular}

Multiplier $\kappa=20 /\left(\theta_{i}-\theta_{e}\right)$, where $\theta_{i}$ - indoor temperature during the heating season is equal to $\theta_{i}=20^{\circ} \mathrm{C} ; \theta_{e}$ - the average outside air temperature during the heating season (Table 2)

The research object of the study is the relations between the thickness of the thermo-insulation layer of the typical details of the wall (see Fig. 4) and its simple and real payback time. The wall was evenly insulated with expanded polystyrene (EPS70) foam having the declared value of the thermal conductivity coefficient (in this study $-\lambda_{\text {dec }}=0.039 \mathrm{~W} /(\mathrm{m} \cdot \mathrm{K})$.

In order to find out the influence of climate and a geographic location on the thickness of the thermo-insulation layer, calculations in 7 Lithuanian cities were performed. The average outside air temperature (Table 2) discussed in this study has been adopted according to data on RSN 156-94 - The Norm on Construction of the Republic of Lithuania (1994) (average data on the 30 year-period).
Table 2. The average outside air temperature during the heating season

\begin{tabular}{l|c|c}
\hline \multicolumn{1}{c|}{ Location } & $\begin{array}{c}\text { The average temperature, } \\
\theta_{e},{ }^{\circ} \mathrm{C}\end{array}$ & $\begin{array}{c}\text { Duration } \\
\text { in days }\end{array}$ \\
\hline Siauliai & 0.6 & 222 \\
Panevezys & 0.4 & 218 \\
Klaipeda & 1.9 & 214 \\
Utena & 0.1 & 221 \\
Dukstas & -0.3 & 223 \\
Kaunas & 0.7 & 219 \\
Vilnius & 0.2 & 225 \\
Lithuania & 0.6 & 220 \\
\hline
\end{tabular}

The problem is that the geographic region of Lithuania in technical documents is evaluated as one climatic region, with an average outside air temperature of $+0.6^{\circ} \mathrm{C}$ during the heating season (Aviza, Turskis 2014). Different outside air temperature can be observed in different climatic zones in Lithuania, and therefore, for using correlation dependence functions, a calculation solution to the thickness of the thermo-insulation layer (EPS70) of the typical details of the wall will be presented in this work.

The calculation methodology for the heat transfer coefficient of partitions and correlation dependence are further analysed. Then, on the basis of the obtained results simple payback and real periods are estimated.

\section{Calculation methodology}

As for this study, general data and formulas for external wall partitions were taken from document STR 2.01.09:2012 Energy Performance of Buildings. Certification of Energy Performance (2012).

The total heat transfer coefficient $U\left(\mathrm{~W} /\left(\mathrm{m}^{2} \times \mathrm{K}\right)\right)$ of the external wall (see Fig. 5) can be calculated as follows:

$$
\begin{gathered}
R_{t}=R_{s i}+R_{s 1}+R_{s e} ; \\
U=\frac{1}{R_{t}}=\frac{1}{R_{s i}+R_{s 1}+R_{s e}},
\end{gathered}
$$

where: $R_{s i}$ - the thermal resistance of the internal surface of the wall $\left(\mathrm{m}^{2} \cdot \mathrm{K} / \mathrm{W}\right) ; R_{s e}$ - the thermal resistance of the external surface of the wall $\left(\mathrm{m}^{2} \cdot \mathrm{K} / \mathrm{W}\right) ; R_{s 1}-$ the sum of the thermal resistance of wall layers $\left(\mathrm{m}^{2} \cdot \mathrm{K} / \mathrm{W}\right)$; $R_{t}$ - the total thermal resistance of external wall construction $\left(\mathrm{m}^{2} \cdot \mathrm{K} / \mathrm{W}\right)$.

The sum of the thermal resistance $R_{s 1}\left(\mathrm{~m}^{2} \cdot \mathrm{K} / \mathrm{W}\right)$ of the wall construction is calculated according to the following expression:

$$
R_{s 1}=R_{1}+R_{2}+\ldots .+R_{n}+\left(R_{q}\right),
$$

where: $R_{q}$ - the thermal resistance of the thin layer $\left(\mathrm{m}^{2} \cdot \mathrm{K} / \mathrm{W}\right) ; R_{1}, R_{2}, \ldots, R_{n}$ - the thermal resistance of the separate layers of the wall $\left(\mathrm{m}^{2} \cdot \mathrm{K} / \mathrm{W}\right)$. The thermal resistance of the separate layers of the wall are calculated as follows: 


$$
R=\frac{d}{\lambda_{d s}}
$$

where: $d$ - the thickness of the layer ( $\mathrm{m}) ; \lambda_{d s}$ - the design value of the thermal conductivity coefficient of expanded polystyrene $(\mathrm{W} /(\mathrm{m} \cdot \mathrm{K}))$.

The main verification condition is the heat transfer coefficient of the external wall partition that must satisfy normative requirements:

$$
U_{w} \leq U_{N . w}
$$

where: $U_{w}$ - the design value of the heat transfer coefficient of the wall partition $\mathrm{W} /\left(\mathrm{m}^{2} \cdot \mathrm{K}\right)$ that directly depends on the investigated object, i.e. thermo-insulation (EPS70) thickness (see Fig. 4(2)); $U_{N . w}$ - the normative heat transfer coefficient of the wall $\mathrm{W} /\left(\mathrm{m}^{2} \cdot \mathrm{K}\right)$ depending on energy efficiency class (see Table 1) and the average outside air temperature during the heating season (Table 2).

When the required thickness of the thermo-insulation layer is obtained (Stankevičius et al. 1997), the period of simple materials and salary (investment) payback is calculated:

$$
P S=\frac{I_{0}}{\Delta S},
$$

where: $I_{0}$ - the amount of investment to additional insulation, $€ / \mathrm{m}^{2} ; \Delta S$ - annual savings, first year cost, $€ /\left(\mathrm{m}^{2} \cdot\right.$ years $)$.

The annual savings are calculated according to the following expression:

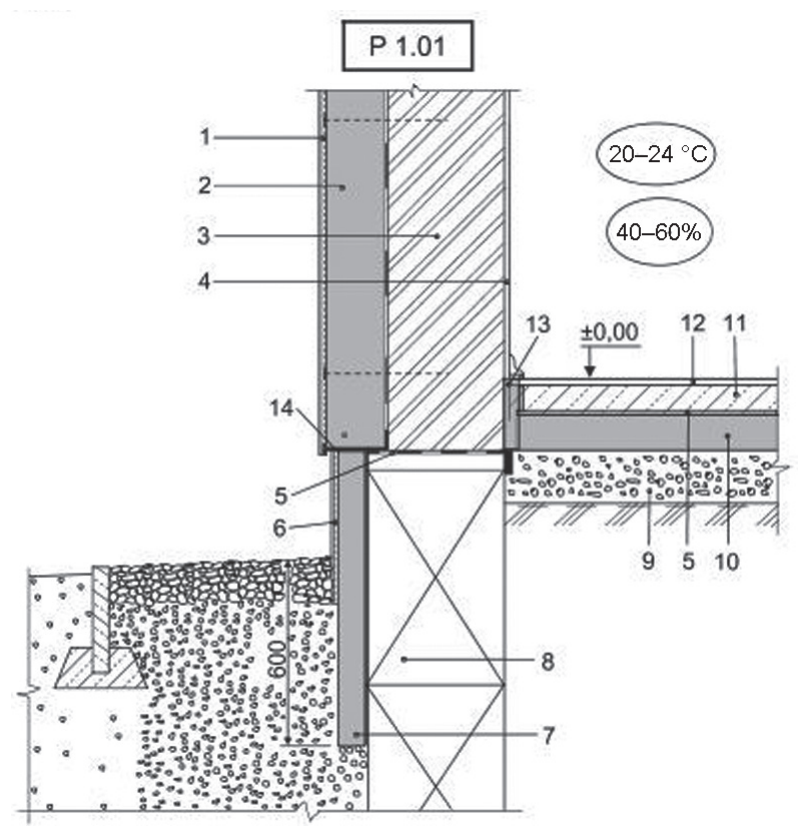

Fig. 4. The partition of the investigated wall: 1 - thin rendering; 2 - thermal insulation (EPS70); 3 - wall; 4 - surface finishing; 5 - horizontal waterproofing; 6 - plinth finishing; 7 - vertical thermal insulation; 8 - foundation; 9 - gravel layer; 10 horizontal thermal insulation; 11 - concrete slab; 12 - floor covering

$$
\Delta S=\left(\frac{\Delta U \cdot \Delta \theta \cdot t \cdot 24}{1000}\right) \cdot E,
$$

where: $\Delta U=U_{1}-U_{2}$ is the difference value of heat transfer coefficients of the wall (before $U_{1}$ and after $U_{2}$ additional insulation) $\mathrm{W} /\left(\mathrm{m}^{2} \cdot \mathrm{K}\right) ; \Delta \theta$ - the difference of inside and outside air temperature during the heating season, ${ }^{\circ} \mathrm{C} ; t$ - the duration of the heating season, days (Table 2); $E$ - heat energy costs, $€ / \mathrm{kWh}$.

The real payback period is calculated according to the expression:

$$
T A L=\frac{-\ln \left(1-d \cdot \frac{I_{0}}{\Delta S}\right)}{\ln (1+d)},
$$

where: $T A L$ - the real payback period, years; $d$ - the discount rate evaluating an increase in energy price, unit parts/year; $I_{0}$ and $\Delta S$ - see Eqn (6).

\section{Research model / element}

A research model has been created for determining correlation functions (Fig. 5). The solutions to the designed model cover:

1. For the purpose of calculations, the typical details of the wall of the residential building of one and two room-apartment were accepted (Table 3).

2 . The thermal resistance of the external surface of the wall is $R_{s e}=0.04 \mathrm{~m}^{2} \times \mathrm{K} / \mathrm{W}$; the thermal resistance of the internal surface of the wall is $R_{s i}=0.13 \mathrm{~m}^{2} \times \mathrm{K} / \mathrm{W}$.

3. The adhesive mortar layer was adopted as a thin layer $R_{q}=0.04\left(\mathrm{~m}^{2} \times \mathrm{K}\right) / \mathrm{W}$ respectively, according to technical regulations on construction STR 2.01.09:2012 (2012).

4. The expanded polystyrene (EPS70) foam was used as insulation according to document ST 124555837.01: 2013 - Expanded Polystyrene Foam Thermal Insulation for Building Partitions (2013) (Fig. 5). The declared value of heat conductivity coefficient is $\lambda_{D}=0.039 \mathrm{~W} /(\mathrm{m} \cdot \mathrm{K})$. The design value of the accepted heat conductivity coefficient is $0.041 \mathrm{~W} /(\mathrm{m} \cdot \mathrm{K})$ (according to document STR 2.01.03:2009 (2009)).

5 . Normative values of the heat transfer coefficient of the wall were accepted according to requirements for technical regulations on construction STR 2.01.09:2012 (2012) assessing temperature adjustment $\kappa=1$. The effect of the location assessed considering temperature adjustment equals $\kappa=20 /(20-$ $\theta_{e}$ ), when $\theta_{e}$ is accepted in Table 2 .

6. Masonry wall - autoclaved aerated concrete blocks, specific weight $-500 \mathrm{~kg} / \mathrm{m}^{3}$, thickness $-250 \mathrm{~mm}$; $\lambda_{d s}=0.153 \mathrm{~W} /(\mathrm{m} \cdot \mathrm{K})$.

7. Thin-reinforced rendering thickness $-5 \mathrm{~mm}$; surface finishing $-15 \mathrm{~mm} ; \lambda_{d s}=0.8 \mathrm{~W} /(\mathrm{m} \cdot \mathrm{K})$.

8. The price of insulation materials (EPS70) and a salary of $47.47 € / \mathrm{m}^{3}$ were accepted. 


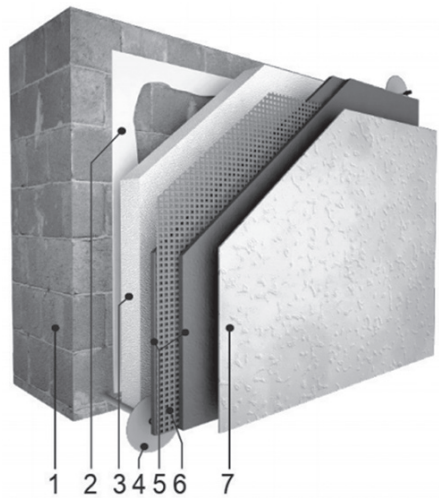

Fig. 5. Details of the wall. Research object - (3) the thickness of the thermo-insulation layer EPS70 of the wall, $\mathrm{mm}$ (for layers see Table 3)

Table 3. The layers of the details of the external wall

\begin{tabular}{|c|c|c|}
\hline No. & Wall layer & $\begin{array}{c}\text { Thickness, } \\
\mathrm{mm}\end{array}$ \\
\hline$*$ & Surface finishing & 15 \\
\hline 1 & $\begin{array}{l}\text { Autoclaved aerated concrete blocks, } \\
\left(500 \mathrm{~kg} / \mathrm{m}^{3}\right)\end{array}$ & 250 \\
\hline 2 & Adhesive mortar layer & 5 \\
\hline 3 & $\begin{array}{l}\text { Expanded polystyrene } \\
\text { (EPS70) foam }\end{array}$ & 110-340 \\
\hline 4 & Anchor with plastic nail & - \\
\hline 5 & $\begin{array}{l}\text { Adhesive mortar coated with } \\
\text { masonry sealer }\end{array}$ & \multirow{3}{*}{5} \\
\hline 6 & Reinforcing mesh & \\
\hline 7 & Decorative coat & \\
\hline
\end{tabular}

9. Thermal energy cost was accepted (the average price of central heating systems in 2014) $E=0.0724 € / \mathrm{kWh}$.

10. Discount rate $d=(-0.062) /(1+0.062)=-0.05838$ (taking $6.2 \%$ of the annual energy increase (Statistics Lithuania 2014)) without assessing the values of interest rate and inflation, because, within a long period, the sum of these indicators is equal to zero). Research calculations were performed using the same model/element and solutions to building design as well as changing only climatic data.

\section{Research results}

The required thickness of the thermo-insulation layer (EPS70) of the sample of a typical wall was calculated according to the methodology for normative requirements for energy efficiency. As provided in Table 6, the final thickness of the wall was calculated using the approximation method of checking the condition of Eqn (5) and changing climatic data.

The thickness of the thermal insulation layer increases proportionally with a rise in energy efficiency class using traditional insulation materials (in this study EPS70) for the thermal insulation of external wall partitions. The normative thickness of the thermal insulation layer increases 2.54 times for buildings with almost un- consumed energy (A++ class), compared with the currently valid minimum requirements pertaining to energy efficiency classes $\mathrm{C}$ and B, as shown in Table 6 .

Qualitative parameters were estimated for determining the correlation between the energy efficiency class of the building and the thickness of the thermal insulation layer of the wall. In this study, only 4 energy performance classes $(\mathrm{C}$ and $\mathrm{B} ; \mathrm{A} ; \mathrm{A}+; \mathrm{A}++)$ were tested because they are the only having normative values of thermal transfer coefficients (Table 1). Classes C and B have been merged into one group, because partitions have the same requirements for heat transfer coefficients. For this reason, energy performance classes $\mathrm{C}$ and $\mathrm{B}$ were assigned 1 point, A class -2 points, $\mathrm{A}+$ class -3 points and class $\mathrm{A}++-4$ points (Table 4).

Table 4. Qualitative parameters of energy performance class

\begin{tabular}{c|c|c}
\hline No. & $\begin{array}{c}\text { Energy performance } \\
\text { class }\end{array}$ & $\begin{array}{c}\text { A qualitative parameter, } \\
x, \text { points }\end{array}$ \\
\hline 1 & $\mathbf{C}$ and $\mathbf{B}$ & 1 \\
\hline 2 & $\mathbf{A}$ & 2 \\
\hline 3 & $\mathbf{A}+$ & 3 \\
\hline 4 & $\mathbf{A}++$ & 4 \\
\hline
\end{tabular}

A polynomial regression function was used for justifying calculations, because this type of the function has greater accuracy. The correlation and determination coefficient equal to unity $(R=+1)$ in all equations was obtained because of only 4 points. This shows there is an absolute direct high-quality link between energy efficiency class and the thickness of the thermal insulation layer.

The carried out research proved that Lithuania should not be regarded as one climatic zone. The currently valid energy efficiency calculation procedure is only suitable for Panevezys and Siauliai regions (Table 5) as they have equal normative requirement values. Therefore, the proposal is to have at least 3-6 climatic zones.

Table 5. Thickness required for the thermo-insulation layer (EPS70) (y), mm

\begin{tabular}{c|l|l}
\hline No. & \multicolumn{1}{|c|}{ Location } & \multicolumn{1}{c}{ Correlation function $(\mathrm{y}), \mathrm{mm}$} \\
\hline 1 & Dukstas & $y=18.333 \cdot x^{3}-165 \cdot x^{2}+506.67 \cdot x-220$ \\
\hline 2 & Utena & $y=20 \cdot x^{3}-175 \cdot x^{2}+525 \cdot x-240$ \\
\hline 3 & Vilnius & $y=18.333 \cdot x^{3}-165 \cdot x^{2}+506.67 \cdot x-230$ \\
\hline 4 & $\begin{array}{l}\text { Panevezys } \\
\text { and Šiauliai }\end{array}$ & $y=18.333 \cdot x^{3}-160 \cdot x^{2}+481.67 \cdot x-210$ \\
\hline 5 & Kaunas & $y=16.667 \cdot x^{3}-150 \cdot x^{2}+463.33 \cdot x-200$ \\
\hline 6 & Klaipeda & $y=16.667 \cdot x^{3}-150 \cdot x^{2}+463.33 \cdot x-220$ \\
\hline $\begin{array}{l}\text { Normative } \\
\text { (Lithuania) }\end{array}$ & $y=28,333 \cdot x^{3}-245 \cdot x^{2}+736,67 \cdot x-220$ \\
\hline
\end{tabular}

here $x$ - Energy performance class, points (Table 4)

Designers, energy consumption auditors and experts have been recommended to calculate the thickness of the thermal insulation layer (EPS70) of the wall of residential buildings (one and two room-apartments) according to the obtained functions of a correlational relationship (Table 5 and Fig. 6). 


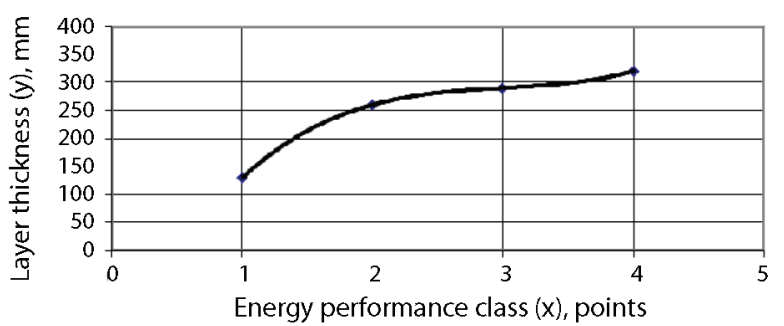

Fig. 6. The diagram of the correlation function (normative value for EPS70)

The estimated annual savings were calculated according to the formula (Eqn (7)). Investigation showed there was no need to split Lithuania into separate areas when calculating the payback period (Tables 7 and 8). Therefore, a common correlational relationship function can be used for all Lithuania (normative requirement). The payback period of the thermo-insulation layer (EPS70) of the wall was estimated using formulas presented in Eqns (9) and (10):

$$
\begin{aligned}
- & \text { simple payback period }\left(y_{1}, \text { years }\right): \\
& y_{1}=0.2969 \cdot x^{3}-2.583 \cdot x^{2}+7.7629 \cdot x-2.1311 ; \\
- & \text { real payback period }\left(y_{2}, \text { years }\right): \\
& y_{2}=0.2298 \cdot x^{3}-2.0095 \cdot x^{2}+6.037 \cdot x-1.2914,
\end{aligned}
$$

where $x$ is the energy performance class of the building as indicated in Table 4. The correlation coefficient is equal to unity $(R=1)$.

\section{Multiple criteria decision support system}

Based on the analysis of the available information, knowledge, expert and decision support systems and, in order to determine the correlation between the thickness of the thermo-insulation layer and its payback period of the external wall, a multiple criteria decision support system for analyzing the correlation between the thickness of the thermo-insulation layer and its payback period of the external wall (DSS-ACTILPW) consisting of a database, a database management system, a model-base, a modelbase management system and the user interface was developed (see Fig. 7).

\subsection{Database}

In order to thoroughly analyse the available alternatives and to obtain an efficient compromise solution, it is often necessary to define them on the basis of a different type of information that should be provided in the most useroriented way.

Economic information on the external wall embraces the cost of the external wall, heat energy costs, investment payback time, interest rate (in case of crediting), etc. This information may be described in minor detail. Crediting may be provided by various sources. There- fore, some additional information on alternative crediting sources and terms might be quite helpful for decision makers.

The characteristics of the technical external wall include the building, energy efficiency class, the price of insulation materials and worker salary, the thermal resistance of the internal and external surfaces of the wall, the thickness of the layer, the thermal conductivity coefficient of the building material used in the layer, etc.

\begin{tabular}{|c|c|}
\hline \multicolumn{2}{|c|}{ Decision maker } \\
\hline \multicolumn{2}{|c|}{ User interface } \\
\hline $\begin{array}{c}\text { Database } \\
\text { management system }\end{array}$ & $\begin{array}{c}\text { Model-base } \\
\text { management system }\end{array}$ \\
\hline $\begin{array}{l}\text { Database: } \\
\text { - initial data tables, } \\
\text { - tables assessing exter- } \\
\text { nal wall solutions, } \\
\text { - tables of multi-variant } \\
\text { design }\end{array}$ & $\begin{array}{l}\text { Model-base: } \\
\text { - a model for developing } \\
\text { alternative variants of the } \\
\text { external wall, } \\
\text { - a model for determining } \\
\text { the initial weights of cri- } \\
\text { teria (including the use of } \\
\text { expert methods), } \\
\text { - a model for establishing } \\
\text { the weight of criteria, } \\
\text { - a model for the multi-var- } \\
\text { iant design of the external } \\
\text { wall, } \\
\text { - a model for multiple cri- } \\
\text { teria analysis and setting } \\
\text { priorities, } \\
\text { - a model for determining } \\
\text { the degree of project util- } \\
\text { ity, } \\
\text { - a model for providing rec- } \\
\text { ommendations. }\end{array}$ \\
\hline
\end{tabular}

The characteristics of an environmental external wall embrace inside and outside air temperature during the heating season, the duration of the heating season, etc.

Fig. 7. Components of DSS-ACTILPW

In a similar way, a possibility of demonstrating the need to possess some other information (i.e. data on the aesthetics of the external wall, etc.) related to the complex efficiency of the analyzed alternative versions of the external wall is suggested.

Qualitative parameters, for determining the correlational relationship between the energy efficiency class of the building and the thickness of the thermal insulation layer of the wall, were estimated. As for this study, only 4 energy performance classes ( $\mathrm{C}$ and $\mathrm{B} ; \mathrm{A} ; \mathrm{A}+; \mathrm{A}++)$ having the normative values of thermal transfer coefficients (Table 1) were tested. For this reason, energy performance class $\mathrm{C}$ and $\mathrm{B}$ was assigned 1 point, $\mathrm{A}-2$ points, $\mathrm{A}+-3$ points and $\mathrm{A}++-4$ points (Table 4 ). 
The presentation of information needed for decision making in the DSS-ACTILPW system may be in conceptual (digital / numerical), textual, graphical (diagrams, graphs, drawing, etc.), photographical, sound (audio), visual (video), augmented reality and quantitative forms. Thus, the presentation of quantitative information involves the systems and subsystems for criteria, measurement units, values and initial weights fully defining the provided variants. Conceptual information means a conceptual description of alternative solutions, criteria and ways determining their values and significance, etc.

Therefore, the DSS-ACTILPW system enables the decision maker to get different conceptual and quantitative information on the external wall from a database and a model-base allowing him/her to analyse the above mentioned factors and make an efficient solution.

The analysis of database structures in decision support systems, according to the type of the solved problem, reveals their various utility. There are three basic types of database structures: hierarchical, network and relational. The DSS-ACTILPW system has a relational database structure when information is stored in the form of tables that contain quantitative and conceptual information. Each table is given a name and is saved in the external memory of the computer as a separate file. Logically linked parts of the table make a relational model. The following tables make the database of the DSS-ACTILPW system:

- Tables of the initial data contain general facts about the external wall considered and information on its deterioration and obsolescence. Reasons for refurbishing and their significance as well as the money intended to be spent on it are also given.

- Tables assessing solutions to the external wall. They contain quantitative and conceptual information on solutions to the alternative external wall.

- Tables of multi-variant design provide quantitative and conceptual information on the interconnection of elements (thin rendering, thermal insulation, wall, surface finishing, horizontal waterproofing, plinth finishing, vertical thermal insulation, foundation, gravel layer, horizontal thermal insulation, concrete slab, floor covering), their compatibility and possible combinations as well as data on the complex multivariant design of the external wall.

The collection, processing and presentation of information on the database in the computer acceptable form make a complicated time-consuming process. The information collected in the database should be reliable, fully describing the external wall as well as enabling the DSSACTILPW system to perform an efficient design of the multi-variant external wall and multiple criteria analysis.

To design the structure of the database and perform its completion, storage, editing, navigation, searching, browsing, etc., the database management system was used.

The tables of refurbishing the assessment of the wall variant contain available variants and their quantitative and conceptual description. The quantitative description of the alternatives deals with the systems and subsystems of criteria fully defining the variants as well as units of the measurement, values and initial weights. The conceptual description defines the alternatives available in the commonly used language giving reasons and providing grounds for choosing a particular criterion, calculating its value, weight, etc. The process of drawing up the tables of refurbishing the assessment of the wall variant consists of the following steps:

- the collection and presentation of general information about the variants under consideration;

- the establishment and conceptual description of the systems and subsystems of criteria,

- establishing criteria for choosing the units of measurement;

- the estimation of the values of the criteria with the description and presentation of the calculation process;

- the determination of the initial weights of the criteria with the description and presentation of the calculation process.

The uniform types of relational tables have been chosen to facilitate entering appropriate data into the database. Such unified database also makes it possible to easily correct and introduce new information as well as to efficiently carry out computation.

The above tables are used as a basis for working out the matrices of decision making. The matrices, along with the application of the model-base and models, allow performing multi-variant design and evaluating multiple criteria for alternative refurbishing projects on the external wall resulting in the selection of the most beneficial variants.

In order to design and realize an effective project on the external wall, the available alternatives should be analyzed. Computer-aided multi-variant design requires the availability of the tables containing data on the interconnection of the elements to be renovated and solutions made as well as their compatibility, possible combination and multi-variant design.

Based on the above tables of the design of the multi-variant external wall, possible variants of the external wall are developed. When using the method of multivariant design suggested by the authors, up to 100000 alternatives to the external wall may be obtained. These versions of the project are checked for their capacity to meet various requirements.

\subsection{Model-base}

Since the efficiency of the variant of the external wall is often determined taking into account different factors, the model-base of the decision support system should include the models enabling a decision maker to do a comprehensive analysis of the available variants and to offer a proper choice. The following models of the model-base are aimed at performing this function: 
- a model for developing alternative variants of the external wall;

- a model for determining the initial weights of criteria (using expert methods);

- a model for establishing the weight of criteria;

- a model for the multi-variant design of the external wall;

- a model for analyzing multiple criteria and setting priorities;

- a model for determining the degree of project utility;

- a model for providing recommendations.

Based on the above models, the DSS-ACTILPW system can develop up to 100,000 alternative versions of the external wall thus performing the analysis of their multiple criteria, determining the degree of utility and selecting the most beneficial variant without human interference.

According to the user's needs, various models may be provided with reference to the model-base management system. When a certain model (i.e. determining the initial weights of criteria) is used, the results of the calculations obtained become the initial data on some other models (i.e. a model for the multi-variant design of the external wall, a model for analyzing multiple criteria and setting priorities) while the results of the latter, in turn, may be taken as the initial data on some other models (i.e. determining the degree of project utility, providing recommendations, etc.).

The management system of the DSS-ACTILPW model base provides the user with the model-base allowing him/her to modify the models available, eliminating those no longer needed and adding some new ones linked with the available ones.

\section{Conclusions}

1. The carried out analysis shows that the variation of the thickness of the thermo-insulation layer of the typical details of the wall depends on energy efficiency class and the type of the geographical location (Table 6). A preliminary selection of thermo-insulation materials/layers has to be done using different functions of correlation dependence for various regions of Lithuania.

2. Comparing standard requirements for the buildings of energy efficiency classes $\mathrm{C}$ and $\mathrm{B}$ and class $\mathrm{A}++$ net zero energy buildings, the required thickness of the thermal insulation layer (EPS70) of the typical details of the wall and price increases 2.54 times while annual savings -1.29 times.

3. The evaluation of the buildings of the same energy efficiency class in different climatic zones of Lithuania has disclosed that the thinnest thermal insulation layer of wall partitions is required in Klaipeda region, while the thickest one - in Dukstas. The greatest influence of fluctuations in climate has been noticed on the buildings of energy efficiency class A. In this category, the required thickness of the thermal insulation layer (EPS70) pertaining to the wall varies by $4 \mathrm{~cm}$ between the warmest and coldest region of Lithuania.

4. According to the conducted research, the longest payback period of contributed funds (price of thermal insulation materials) is achieved within the period of up to 6.76 years (real payback period -5.53 years) in the city of Klaipeda (Table 8).

5. The DSS-ACTILPW system can create up to 100,000 alternative versions of the external wall thus analyzing their multiple criteria, determining the degree of utility and selecting the most beneficial variant without human interference.

Table 6. The thickness of the calculated thermo-insulation layer (EPS70) (in accordance with regulatory requirements for external walls)

\begin{tabular}{l|c|c|c|c|c|c|c|c|c}
\hline \multirow{2}{*}{$\begin{array}{c}\text { Energy } \\
\begin{array}{c}\text { performance } \\
\text { class }\end{array}\end{array}$} & $\begin{array}{c}\text { Tithuania } \\
\text { (normative) }\end{array}$ & Dukstas & Utena & Vilnius & Panevezys & Siauliai & Kaunas & Klaipeda & $\begin{array}{c}\text { Difference } \\
\%\end{array}$ \\
\hline \multicolumn{1}{c|}{1} & 2 & 3 & 4 & 5 & 6 & 7 & 8 & 9 & 10 \\
\hline C and B & 130 & 140 & 130 & 130 & 130 & 130 & 130 & 110 & 21.43 \\
A & 260 & 280 & 270 & 270 & 260 & 260 & 260 & 240 & 14.29 \\
A+ & 290 & 310 & 300 & 300 & 290 & 290 & 290 & 270 & 12.90 \\
A++ & 330 & 340 & 340 & 330 & 330 & 330 & 320 & 300 & 11.76 \\
\hline Difference, t & 2.54 & 2.43 & 2.62 & 2.54 & 2.54 & 2.54 & 2.46 & 2.73 & \\
\hline
\end{tabular}

Table 7. The calculated simple payback period of the thermo-insulation layer of the wall (EPS70)

\begin{tabular}{l|c|c|c|c|c|c|c|c|c}
\hline \multirow{2}{*}{$\begin{array}{c}\text { Energy } \\
\begin{array}{c}\text { performance } \\
\text { class }\end{array}\end{array}$} & $\begin{array}{c}\text { Sithuania } \\
\text { (normative) }\end{array}$ & Dukstas & Utena & Vilnius & Panevezys & Siauliai & Kaunas & Klaipeda & $\begin{array}{c}\text { Difference } \\
\%\end{array}$ \\
\hline \multicolumn{1}{c}{1} & 2 & 3 & 4 & 5 & 6 & 7 & 8 & 9 & 10 \\
\hline C and B & 3.35 & 3.37 & 3.26 & 3.22 & 3.38 & 3.38 & 3.45 & 3.32 & 6.56 \\
A & 5.44 & 5.50 & 5.49 & 5.43 & 5.46 & 5.44 & 5.55 & 5.70 & 4.80 \\
A+ & 5.93 & 5.95 & 5.96 & 5.89 & 5.95 & 5.92 & 6.04 & 6.24 & 5.71 \\
A++ & 6.59 & 6.38 & 6.60 & 6.33 & 6.62 & 6.58 & 6.51 & 6.76 & 6.39 \\
\hline Difference, t & 1.97 & 1.90 & 2.03 & 1.96 & 1.96 & 1.95 & 1.89 & 2.04 & \\
\hline
\end{tabular}


Table 8. The calculated real payback period of the thermo-insulation layer of the wall (EPS70)

\begin{tabular}{|c|c|c|c|c|c|c|c|c|c|}
\hline \multirow{2}{*}{$\begin{array}{c}\text { Energy } \\
\text { performance } \\
\text { class }\end{array}$} & \multicolumn{8}{|c|}{ Real payback period, years } & \multirow{2}{*}{$\begin{array}{c}\text { Difference } \\
\%\end{array}$} \\
\hline & $\begin{array}{r}\text { Lithuania } \\
\text { (normative) }\end{array}$ & Dukstas & Utena & Vilnius & Panevezys & Siauliai & Kaunas & Klaipeda & \\
\hline 1 & 2 & 3 & 4 & 5 & 6 & 7 & 8 & 9 & 10 \\
\hline $\mathrm{C}$ and $\mathrm{B}$ & 2.97 & 2.98 & 2.89 & 2.87 & 3.00 & 2.99 & 3.05 & 2.95 & 1.31 \\
\hline $\mathbf{A}$ & 4.58 & 4.63 & 4.62 & 4.57 & 4.60 & 4.58 & 4.66 & 4.77 & 0.60 \\
\hline $\mathbf{A}+$ & 4.94 & 4.96 & 4.96 & 4.91 & 4.96 & 4.93 & 5.02 & 5.17 & 0.90 \\
\hline $\mathbf{A}++$ & 5.41 & 5.27 & 5.42 & 5.23 & 5.43 & 5.40 & 5.35 & 5.53 & 2.32 \\
\hline Difference, $\mathrm{t}$ & 1.83 & 1.76 & 1.87 & 1.82 & 1.81 & 1.81 & 1.75 & 1.88 & \\
\hline
\end{tabular}

\section{References}

Aviza, D.; Turskis, Z. 2014. An empirical analysis of correlation between the thickness of a thermal insulation layer of the floor and the payback period, Journal of Civil Engineering and Management 20(5): 760-766.

http://dx.doi.org/10.3846/13923730.2014.937356

Aviza, D.; Turskis, Z.; Volvaciovas, R. 2013. Correlation analysis of thermo-insulation layer thickness and its payback period of the typical pitched roof detail, Procedia Engineering 57: 120-126.

BUILD UP Skills - Lithuania. 2013 [online], [cited 22 January 2015]. Available from Internet: http://www.buildupskills.eu/en/national-project/lithuania

Buildings Performance Institute Europe (BPIE). 2015 [online], [cited 22 January 2015]. Available from Internet: http://www.buildingsdata.eu/

Certification Center of Building Products (SPSC). 2015 [online], [cited 22 January 2015]. Available from Internet: http://www.spsc.lt/

Deng, S.; Wang, R. Z.; Dai, I. Y. 2014. How to evaluate performance of net zero energy building - A literature research, Energy 71: 1-16. http://dx.doi.org/10.1016/j.energy.2014.05.007

Directive 2010/31/EU of the European Parliament and of the Council of 19 May 2010 on the energy performance of buildings, Official Journal of the European Union L $153 / 13$.

Kaynakli, O. 2012. A review of the economical and optimum thermal insulation thickness for building applications, $R e$ newable and Sustainable Energy Reviews 16: 415-425. http://dx.doi.org/10.1016/j.rser.2011.08.006

Kurnitski, J.; Saari, A.; Kalamees, T.; Vuolle, M.; Niemelä, T. 2011. Cost optimal and nearly zero (nZEB) energy performance calculations for residential buildings with REHVA definition for nZEB national implementation, Energy and Buildings 43(11): 3279-3288.

http://dx.doi.org/10.1016/j.enbuild.2011.08.033
Statistics Lithuania. 2014 [online], [cited 22 May 2014]. Available from Internet: http://db1.stat.gov.lt/statbank

Marszal, A. J.; Heiselberg, P.; Jensen, R. L.; Nørgaard, J. 2012. On-site or off-site renewable energy supply options? Life cycle cost analysis of Net Zero Energy Building in Denmark, Renewable Energy 44: 154-165. http://dx.doi.org/10.1016/j.renene.2012.01.079

RSN 156-94 Building Climatology. The Norm on Construction of the Republic of Lithuania. Vilnius, 1994. 22 p.

Stankevičius, V.; Dapkus, G.; Burlingis, A. 1997. Pastatu atitvaru apšiltinimo atsiperkamumas [Payback period of building partitions' insulation]. Kaunas: ASI. 19 p. (in Lithuanian).

ST 124555837.01:2013 Thermal insulation of building partitions with expanded polystyrene foam. Technical construction regulation. Vilnius, 2013 (in Lithuanian).

STR 2.01.09:2012 Energy Performance of Buildings. Certification of energy performance. Technical construction regulation. Vilnius, 2012 (in Lithuanian).

STR 2.01.03:2009 Declared and design values of thermal technical variables of construction materials and products. Technical construction regulation. Vilnius, 2009 (in Lithuanian).

The Ministry of Economy of Republic of Lithuania. 2015 [online], [cited 22 January 2015]. Available from Internet: http://www.ukmin.lt/ (in Lithuanian).

The Energy Independence and Security Act of 2007 (EISA). 2007. USA Public Law, 110-140.

Kong, X.; Lu, S.; Wu, Y. 2012. A review of building energy efficiency in China during "Eleven Five-Year Plan" period, Energy Policy 41: 624-635. http://dx.doi.org/10.1016/j.enpol.2011.11.024

Donatas AVIŽA. PhD student at the Department of Construction Technology and Management, Vilnius Gediminas Technical University, Vilnius, Lithuania. Master of Science (civil engineering) from VGTU, 2006. Research interests: building construction, energy performance of buildings, construction management, multiple criteria analysis and decision making theories.

Zenonas TURSKIS. Prof. Dr of Technical Sciences, a senior research fellow at the Laboratory of Construction Technology and Management, Vilnius Gediminas Technical University. Research interests: building technology and management, decision-making theory, computer-aided automation in design, expert systems.

Artūras KAKLAUSKAS. Dr Habil. and the head of the Department of Construction Economics and Real Estate Management and the Vice-director of the Institute of Internet and Intelligent Technologies, Vilnius Gediminas Technical University. Lithuanian Science Prize Laureate, Expert member of Lithuanian Academy of Sciences. Editor of International Journal of Strategic Property Management, Journal of Civil Engineering and Management and Facilities for Central and Eastern Europe. Participated in 9 projects Framework 5 and 6, the author of more than 221 research publications and 7 monographs. 